\title{
Gaudium et spes, globalizace a rozvojový svět
}

\section{Shaji G. Kochuthara}

\section{Úvod}

Ačkoli byl termín „globalizace“ uživán před II. vatikánským koncilem, ve svém současném významu vznikl tento pojem později (v 70. letech 20. stol.). V Gaudium et spes (dále pouze GS) či v jiných koncilních dokumentech tedy nenajdeme odkazy ke „globalizaci“, jak o ní mluvíme dnes. GS však předkládá vizi potřeby propojeného světa, $v$ němž jsou všichni vztaženi $k$ sobě navzájem $v$ bratrství a solidaritě. $V$ tomto článku, který čerpá inspiraci z GS a pozdějších církevních dokumentů, budeme analyzovat globalizaci, zvláště z perspektivy rozvojového světa. Mnohé z konkrétních uváděných odkazů budou $\mathrm{z}$ indické situace, ale podobné situace lze najít i v jiných částech světa.

GS uvažuje o významu lidské existence a činnosti v tomto světě. Spása nepřichází díky útěku od světa, nýbrž účastí na světě inspirovanou vírou. Ačkoli se GS zabývá ekonomickým, sociálním, kulturním, národním a mezinárodním životem, není to zásadně socio-politicko-ekonomický dokument. Jeho vize je zásadně teologická. Církev se především snaží zkoumat „znamení časů a vykládat je ve světle evangelia“, a zjevuje Boží úmysl týkající se celkového povolání člověka, a proto vede mysl $\mathrm{k}$ řešením plně lidským “. ${ }^{2}$ Když se tedy díváme do GS a následných dokumentů, nehledáme především nové sociologické a ekonomické teorie, ale snažíme se pochopit a vyložit svět a vývoje v něm ve světle víry.

\section{Globalizace}

Je obtížné definovat globalizaci. Bývalý ekonom Světové banky Joseph Stiglitz ve své knize Globalizace a co je na ní znepokojivého definuje globalizaci jako odstranění překážek pro volný obchod a těsnější integraci národních ekonomik. Stiglitz je přesvědčen, že globalizace mủže být dobrá, jeho působení v jedné z globálních institucí mu však také z první ruky ukázalo zničující účinky, jaké taktiky těchto institucí mohou mít na chudé lidi v rozvojových zemích. ${ }^{3}$ Mnozí však nepovažují globalizaci za pouhý ekonomický jev, ač to snad je její nejlépe viditelný rozměr. Globalizace je také jev sociální, kulturní a politický. N. R. Narayana Murthy, spoluzakladatel a výkonný předseda společnosti Infosys, definuje globalizaci na dvou úrovních:

1 Dokumenty II. vatikánského koncilu, Kostelní Vydří: Karmelitánské nakladatelství, 2002. Konstituce Gaudium et spes, čl. 4. Dále pouze GS a číslo př́slušného oddílu.

2 GS 11.

3 Srov. Joseph STIGLITZ, Globalization and its Discontents, London: Penguin Books, 2002, s. ix. 
„Na makro úrovni je to o hladkém toku kapitálu, služeb, zboží a práce např́č zeměkoulí. Je to také o globálním sdílení myšlenek, poznatků a kultury. Je to o vytváření sdílené starosti a plánu na globální otázky, jako je chudoba, AIDS a životní prostředí... Na mikroekonomické či firemní úrovni je to o získávání kapitálu tam, kde je nejlevnější, získávání talentu tam, kde je nejlépe dostupný, vyrábění tam, kde je to nejefektivnější, a prodávání tam, kde jsou trhy, bez omezení národními hranicemi. ${ }^{\text {“4 }}$

Na jednu stranu považovat globalizaci za špatnou samu o sobě nebo za př́ícinu všech problémů $\mathrm{v}$ tomto světě zřejmě pramení $\mathrm{z}$ př́lilš pesimistického náhledu. $\mathrm{Na}$ druhou stranu představovat globalizaci jako všelék na všechny problémy, jimž svět čelí, a jako jediné dostupné řešení se zdá být př́liš optimistické.

Obecně řečeno, $v$ rozvojových zemích, jako je Indie, je globalizace vítána elitou a podnikovým sektorem. Zvláště nová generace mladých lidí, kteř́ jsou zaměstnáni v IT, managementu a př́ibuzných sektorech, jsou silní zastánci globalizace, zatímco mnozí z těch, kdo jsou zaměstnáni v zemědělství, chudí a ti, kdo pracují pro sociální blaho, jsou proti ní.

\section{Globalizace a ekonomický vývoj}

\section{Může rozvojová země, jako je Indie, přežít bez globalizace?}

Narayana Murthy se domnívá, že Indie se musí globalizace chopit a lépe se integrovat s globálními trhy. Jeho argumenty lze shrnout takto:

Jediný způsob, jak vymýtit chudobu v Indii, je vytváření pracovních míst. Počet nezaměstnaných v Indii se odhaduje kolem 250-300 miliónů. Každý rok k tomu přibývá asi 35-40 miliónů nových hledačů práce. Nadto více než $65 \%$ populace žije ve venkovských oblastech a jejich hlavní živobytí je ze zemědělství, které přispívá jen $26 \%$ HDP. S poukazem na očekávanou míru růstu v zemědělském sektoru tvrdí, že do roku 2017 je třeba přesunout 100 až 120 miliónů lidí ze zemědělství do jiných sektorů. Zkrátka, každý rok musí 45 až 50 miliónů lidí najít novou práci. Podle něj je řešením vytvořit pracovní místa v nízko-technologickém výrobním sektoru, což vyžaduje značné zvýšení vývozu. To vyžaduje posílení interakce s globálními trhy. $\mathrm{O}$ tom právě podle Murthyho globalizace je. ${ }^{5}$

Když Indie získala nezávislost (1947), príijala polosocialistickou ekonomickou politiku. V roce 1991 byla přijata nová ekonomická politika liberalizace, která dává více svobody pro ekonomickou aktivitu a předávání globálního propojení, což vede k privatizaci a globalizaci. Pozitivní účinky této nové politiky lze vidět ve zvýšení míry růstu HDP, přímých zahraničních investic, devizových transakcí a využívání subdodavatelských vztahů (outsourcing). Indie je často uváděna jako jedna z nejrychleji rostoucích ekonomických mocností. Předpovídá se, že do roku 2030 se Indie může stát druhou největší světovou ekonomikou a do roku 2050 zcela největší. Liberalizace a globalizace však mají i negativní účinky, totiž růst nezaměstnanosti, zvětšování nerovnosti, za-

4 N. R. Narayana MURTHY, Making Globalization Work for India, Mumbai: Nani A. Palkhivala Memorial Trust, 2007 , s. 14.

5 Srov. tamtéž, s. 14-20. 
nedbávání zemědělství a široce rozšířenou chudobu. ${ }^{6}$ Procento lidí žijících pod hranicí chudoby může naznačit přetrvávající chudobu a narůstající nerovnost. Podle statistiky Reserve Bank of India procento těch, kdo jsou pod hranicí chudoby, bylo 35,97 v letech 1993-1994, 26,10 v letech 1999-2000 a 21,80 (na základě smíšeného zjištovacího období) a 27,50 (na základě rovnoměrného zjištovacího období). ${ }^{7}$ Statistická data poskytovaná různými agenturami spolu nesouhlasí a kritérium pro stanovování hranice chudoby je odlišné a matoucí. Kritérium př́jmu k stanovení hranice chudoby v Indii je založeno na datech z let 2004-2005, kde se říká, že celoindická úroveň minimálního př́jmu pro venkovské oblasti na osobu na měsíc by mělo být 356,30 rupií a pro městské oblasti 538,60 rupií (v současné době 1 USD je asi 65 indických rupií). ${ }^{8}$ Avšak podle odhadu Světové banky z roku 2005 41,6 \% celkové indické populace spadá pod mezinárodní hranici chudoby 1,25 USD na den. ${ }^{9}$ Nedávno vznikla kvůli kritériu k definování hranice chudoby vášnivá debata. Prohlášení Indického plánovacího výboru před Nejvyšším soudem Indie tvrdí, že při započítání inflace je hranice chudoby pro městskou osobu 32,50 rupií na osobu a den a pro venkovskou osobu 29,30 rupií na osobu a den. To vyvolalo bouři nevole. Podle těchto hranic chudoby Plánovací výbor odhaduje, že v letech 2010-2011 je 407,4 miliónů lidí pod hranicí chudoby. ${ }^{10}$ At je kritérium pro výpočet jakékoli, je také zřejmé, že mnoho lidí žije těsně nad hranicí chudoby. Navíc je třeba vzít v úvahu názory, že více než 70 \% lidí je chudých. ${ }^{11}$

Chudoba v Indii existovala ještě před začátkem liberalizace a globalizace. Je však vhodné uvážit, že růst HDP v posledních desetiletích, zdůrazňovaný jako argument ve prospěch globalizace, se v životě mnoha lidí neodráží. To poukazuje na rozšiřující se propast mezi chudými a bohatými. Podobně mnozí nepřijímají tvrzení, že globalizace vytváří více pracovních příležitostí. Poukazuje se na to, že v posledních letech se počet nezaměstnaných osob zvýšil. ${ }^{12}$

Zemědělské sektory kvůli globalizaci hodně utrpěly. Zemědělská půda malých farmářů je zabírána, aby se vytvářely Zvláštní ekonomické zóny (SEZ), aniž by jim byla dána dostatečná náhrada a aniž by byli rehabilitováni. Ačkoli na místech, jako je Nandigram ${ }^{13}$ v Západním Bengálsku, farmáři úspěšně vzdorovali násilnému získání své půdy, na mnoha jiných místech se jim to nepodařilo. Protože dotace jsou sníženy nebo odebrány, mnozí nemohou pokračovat v obdělávání půdy. Vezměte například ty tisíce zemědělců, kteří v posledních několika letech spáchali sebevraždu.

6 (c) Prezentace Supreti TYAGI, New Economic Policy (on-line), dostupné na: http://www.scribd.com/doc/13709734/New-Economic-Policy-1991, citováno dne 20. 11. 2015.

7 @ RESERVE BANK OF INDIA, Table 162: Number and Percentage of Population below Poverty Line (on-line), dostupné na: http:// www.rbi.org.in/scripts/PublicationsView.aspx?id=13750, citováno dne 20. 11. 2015.

8 (C) Shankar CHATTERGEE, Estimation of Rural Poverty: A Discussion with Reference to India, Paper presented at WYE City Group on Rural Development and Agriculture Household Income, at FAO Headquarters, Rome, June 11-12, 2009 (on-line), dostupné na: http://www.fao.org/fileadmin/templates/ess/pages/rural/wye_city_group/2009/paper_3_1_chatterjee_ITALY.doc, citováno dne 20. 11. 2015 .

9 () THE WORLD BANK, Overview (on-line), dostupné na: http://www.worldbank.org/en/country/india/overview, citováno dne 20. 11. 2015.

10 Srov. @ Kirit PARIKH, The Poverty Line Debate, Hindustan Times 2. 4. 2012 (on-line), dostupné na: http://www.hindustantimes.com/ News-Feed/ColumnsOthers/The-poverty-line-debate/Article1-752547.aspx, citováno dne 2. 4. 2012.

11 Např. N. C. Saxena, člen Národní poradní rady, se domnívá, že více než 70 \% Indů je chudých. Srov. @ About 70 percent of India si poor: NAC member, Zeenews March 25, 2012 (on-line), dostupné na: http://zeenews.india.com/business/news/economy/about-70-percent-of-india-is-poor-nac-member_44536.html, citováno dne 20. 11. 2015.

12 () Unemployment rate increases in India, The Times of India Jun 23, 2013 (on-line), dostupné na: http://articles.timesofIndia.Indiatimes.com/2013-06-23/India/40146190_1_urban-India-urban-women-rural-women, citováno dne 20. 11. 2015.

13 V Nandigram v Západním Bengálsku se vláda vedená Komunistickou stranou indických marxistů (CPIM) rozhodla vyvlastnit $10000 \mathrm{akrů}\left(40 \mathrm{~km}^{2}\right)$ půdy od zemědělců na Zvláštní ekonomickou zónu (SEZ), aby ji společnost Salim Group sídlící v Indonésii využila k industrializaci. Zemědělci tomu vzdorovali, což vedlo k široké vlně násilí, zabíjení a znásilňování mnohých policisty a údajně pracovníky strany CPIM v březnu 2007. Nakonec byla vláda donucena projekt opustit. Může být paradoxní, že CPIM, která se prohlašuje za ochránce zemědělců, jednala proti nim a rozpoutala proti nim násilí. Nakonec CPIM, která v Západním Bengálsku vládla asi tř̌i desetiletí, prohrála parlamentní volby v roce 2011. 
Ř́ká se, že jen ve státě Gujarat, státě, který je často předkládán jako vzor rozvoje a kde byl současný indický premiér dlouho hlavním ministrem, spáchalo v posledních 10 letech sebevraždu více než 16000 zemědělců. ${ }^{14} \mathrm{~K}$ tomu připočtěte tisíce zemědělců, kteří spáchali sebevraždu v Biharu, Uttar Pradeshi a jiných státech.

Jeden z hlavních předpokladů pojetí globalizace podle Washingtonského konsensu je role zahraničních investic. Podle toho „osvobození “ trhů podporuje ekonomický růst tím, že přitahuje mezinárodní investory. Zahraniční firmy mají přinést technickou odbornost a př́stup k zahraničním trhům a finančním zdrojům, a tak vytvářet nové př́ležitosti zaměstnání. Má to však rubovou stranu, totiž že velké globální korporace často zničí místní konkurenci a domácí průmysl. Např. Coca-Cola a Pepsi zničily mnoho místních výrobců nealkoholických nápojů všude po světě. Jestliže je jedinou normou konkurence, pak malorozsahové průmysly a firmy neuspějí, spíše jsou zničeny. To jen přidává $\mathrm{k}$ počtu chudých, ačkoli se akumulace bohatství velkými firmami objeví v růstu HDP.

Ve svém článku Překročit washingtonské pojetí vývoje $e^{15}$ Thomas Pogge ukazuje, že oficiální statistiky o chudobě vydávané Světovou bankou ohledně rozvrhu na dosažení prvního Rozvojového cíle tisíciletí (Millenium Development Goal 1), který tvrdí, že chudoba byla snížena, neodpovídají skutečnosti. Podle něj se naopak chudoba a podvýživa zvyšuje. Říká také, že v posledních jedenadvaceti letech, od konce Studené války, asi 380 miliónů lidí zemřelo z prríčin souvisejících $\mathrm{s}$ chudobou. „Přes všechny proklamované ideály, naše zdánlivě vznosné deklarace, chudoba a zbavení lidských práv, které ji provází, přetrvávají v masivním měřítku. Přetrvávají i v době, kdy se zvyšuje globální průměrný př́ijem a svět jako celek si vede docela dobře." Pogge je toho názoru, že za to je odpovědný nesmírný rozsah nerovností, které během období globalizace narostly v rozložení globálního příjmu na domácnost. V roce 2005 horních $5 \%$ světové populace dostalo $46,36 \%$ globálního př́ijmu na domácnost, dalších $20 \%$ téměř stejný poměr (tj. horní čtvrtina měla 90,34 \% globálního př́imu na domácnost), zatímco ostatní tři čtvrtiny dohromady měly jen 9,66 \%; nejchudší čtvrtina měla jen 0,78 \% . Na základě statistických dat Pogge tvrdí, že z období globalizace těžilo jen nejbohatších $5 \% .^{16}$

\section{Globalizace a ekonomická solidarita}

Globalizace nabízí velké možnosti rozvoje prostřednictvím obchodu a finančních vazeb mezi národy a distribuce kapitálu a bohatství. Pokrok v technologii, komunikačních médiích a odstranění/uvolnění mezinárodních obchodních překážek umožnil globální společenství. Ačkoli tato narůstající propojenost národů všude na zemi je velmi vítaným znamením, ostré nerovnosti, vykořistování, nadvláda, útlak a korupce pokračují v různých podobách. Nerovnosti mezi rozvinutými a rozvojovými zeměmi rychle rostou. Nerovnosti se zvětšují i v rámci rozvinutých zemí. ${ }^{17}$ Slovy GS: „Zatímco velká masa lidí postrádá dosud to nejnutnější, někteří lidé, a to i v zemích méně vyvinutých, žijí v nadbytku nebo plýtvají hodnotami.“18

14 Srov. Mallika SARABHAI, Modi and His Mayajaal, The Week 30. 10. 2011, s. 98.

15 Thomas POGGE, Transcending the Washington View of Development, in: Towards a Strong Global Economic System: Revealing the Logic of Gratuitousness in the Market Economy, ed. Saju CHACKALACKAL, Bangalore: Dharmaram Publications, 2013, s. 73-101.

16 Srov. tamtéž, s. 84-86.

17 Podle Poggeho došlo v období globalizace k masivnímu nárůstu vnitronárodní nerovnosti v téměř všech zemích, včetně těch, které dosáhly vysoké míry národního ekonomického růstu. Tamtéž, s. 90-91.

18 GS 63. 
Zpočátku se mnoho lidí v zemích, jako je Indie, obávalo, že globalizace je forma ekonomického kolonialismu, a tedy vykořistování. Lidé $\mathrm{v}$ rozvinutých zemích globalizaci vnímali spíše pozitivně. Ale nyní již mnozí lidé v rozvinutých zemích zřejmě nejsou z globalizace tak nadšeni, zejména od ekonomické recese. Milióny lidí v rozvinutých zemích ztratily zaměstnání, když mnoho firem prresunulo své výrobní jednotky do jiných zemí, kde je práce levná. $\mathrm{K}$ tomu je třeba připočíst milióny pracovních míst přesunutých do zahraničí. Je pravda, že řada lidí v zemích, kde se otvírají výrobní jednotky a vytvářejí pracovní místa, $\mathrm{z}$ toho má prospěch. Často však mnohonárodní společnosti uzavírají smlouvy s místními vládami, aby byly přijaty jejich vlastní podmínky. A tak, ačkoli má $\mathrm{z}$ toho mnoho lidí v rozvojových zemích prospěch, zisk mnohonárodních firem se nesmírně zvýšil a tento růst je bez jakékoli solidarity, protože nejsou odpovědné nikomu, ani ve svých domácích zemích, ani v zemích, kde otevřely své jednotky. $V$ důsledku toho je rozvoj do značné míry rozvojem velkých firem. Tento nedostatek solidarity posiluje nerovnosti, nespravedlnost, vykořistování a následně chudobu a utrpení. Nebude-li tomu globalizace věnovat pozornost, stane se "globalizací lhostejnosti“, jak opakovaně varoval papež František. ${ }^{19}$

Nedostatek rovnováhy a nerovnost ve vývoji činí chudé chudšími. Vezměme například město Bangalore, indické IT centrum, město, v němž žiji. Desetitisíce lidí našly práci v softwarových společnostech a $\mathrm{BPO}$, které jim nabízejí velmi dobré platy. Ale velký počet lidí je zaměstnán v nízkopř́ijmových sektorech; mnozí nemají jistou práci či vůbec žádnou práci. Je tu řada lidí, kteří vydělávají více než 100000 rupií měsićně. Ale v tomtéž městě jsou stovky tisíců lidí, kteří vydělávají jen 2000 rupií. Často je to př́ijem pro celou rodinu. $S$ ekonomickým růstem ve městě velmi zdražily potraviny, bydlení, vzdělání, zdravotní péče atd. Zkrátka, takzvaný rozvoj v období globalizace nezlepšil život chudých; jejich život se spiše stal zbědovanějším.

To vše objasňuje, že volný obchod sám k zajištění sociální spravedlnosti nestačí. „Ekonomie potřebuje etiku, aby správně fungovala - ne jakoukoli etiku, ale etiku, která je zaměřená na lidi. ${ }^{\text {“20 }}$ Světový výbor pro sociální rozměr globalizace podtrhuje, že globalizace musí být regulována na základě všeobecně sdílených hodnot a úcty k lidským právům. Uznává, že „[g]lobalizace se rozvinula v etickém vakuu, kde se tržní úspěch a selhání stávaly posledním standardem chování a kde postoj ,vítěz bere všechno' oslabuje tkaninu společenství a společnostíi “. ${ }^{21}$ Jakýkoli ekonomický systém a rozvojové programy by měly uznávat „ústřední postavení lidské osoby““.22 Jak zdůraznilo GS: „Hlavním účelem výroby však není pouhé zvyšování počtu výrobků, zisk ani moc, ale služba člověku, celému člověku. ${ }^{\text {“23 }}$

Jen bude-li globalizace založena na principu solidarity, zajistí spravedlnost a distribuci bohatství. Jinak jen zintenzivní a zachová nespravedlnost na globální úrovni. GS podtrhuje potřebu sdílení ve spravedlnosti a lásce: „Bůh určil zemi a všechno, co je na ní, k užívání všem lidem a národům, takže stvořených statků se má dostat všem spravedlivou měrou; to žádá spravedlnost provázená láskou. ${ }^{\prime 24}$ Ačkoli to bylo řečeno před začátkem globalizace, tato vize sdílení ve spravedlnosti je zvláště platná v kontextu globalizace, protože „pokoj pro nás všechny pochází ze spravedlnosti

19 Srov. FRANTIŠEK, Laudato si', č. 52.

20 BENEDIKT XVI., Caritas in veritate, č. 45. Dále pouze CV a číslo příslušného oddílu.

21 WORLD COMMISSION ON THE SOCIAL DIMENSION OF GLOBALIZATION, A Fair Globalization: Creating Opportunities for All, Geneva: ILO Publications, 2004, č. 37, s. 7.

$22 \mathrm{CV} 47$.

23 GS 64.

24 GS 69. 
pro každého z nás“ ${ }^{25}$ Nespravedlnost konaná kdekoli v globalizovaném světě nepř́íznivě ovlivní mír, harmonii a vývoj v kterékoli jiné části světa.

„Boží království“ předkládá vizi lidské společnosti, která žije v solidaritě, lidské společnosti, která žije jako rodina, kde Bůh je Otec všech a všichni jsou bratři a sestry. „Rozvoj národů závisí především na uznání, že lidská rasa je jediná rodina pracující společně v skutečném sdílení. “26 Soutěživost a zisk by neměly trh odcizit od solidarity s lidskou rodinou. To může zajistit jen „civilizace lásky“. ${ }^{27}$

\section{Korupce, globalizace a neoliberalismus}

Nechci tvrdit, že korupce je vynález globalizace. Globalizace však dala korupci nové tváře. Studie vydaná v listopadu 2010 mezinárodní skupinou Global Financial Integrity (GFI) říká, že korupce v Indii po liberalizaci značně narostla. Podle její zprávy byly v letech 2002 až 2006 ztráty vlády v důsledku korupce 16 miliard USD (720 miliard rupií) ročně. ${ }^{28}$ Jak uvádí Arundhati Roy:

„Před dvaceti lety, když se na nás snesla éra ,liberalizace, privatizace a globalizace‘, ř́kali nám, že je třeba privatizovat jednotky veřejných sektorů a veřejnou infrastrukturu, protože jsou korumpované a nevýkonné. Ř́kali nám, že ten problém je systémový. Ted’, když je téměř všechno zprivatizováno, když naše řeky, hory, lesy, nerosty, voda, elektřina a komunikační systémy jsou prodány soukromým korporacím, zjištujeme, že korupce exponenciálně vzrostla, nárůst korupce překonal, co jsme si dovedli představit. “ ${ }^{\prime 29}$

$\mathrm{V}$ posledních letech byl jednou $\mathrm{z}$ rozšířených oblastí korupce $\mathrm{v}$ Indii nákup půdy, zvláště pro mnohonárodní korporace. Snad je potřeba, aby mnohonárodní korporace dostávaly privilegia a výjimky, aby měly zájem přijít. Když je to však za cenu života chudých, popírání jejich základních lidských práv, je třeba to znovu uvážit. Navíc často za takovými smlouvami a dohodami politikové a byrokrati dostávají desítky miliónů rupií za snadné dohody podle podmínek těchto korporací. Korupce tedy zrazuje zájmy obyčejných lidí, zvláště chudých. Když Arundhati Roy mluvil 27. ledna 2003 na Life After Capitalism na Světovém sociálním fóru v Porto Alegre v Brazílii pořádaném společenstvím Znet, řekl:

„Jak narůstá nerovnost mezi bohatými a chudými, boj o získání zdrojů zesiluje. Aby korporativní globalizace prosadila své ,milenecké dohody', zkorporatizovala naše úrody, vodu, kterou pijeme, vzduch, který dýcháme, a sny, které sníme, potřebuje mezinárodní konfederaci věrných, zkorumpovaných, autoritativních vlád $\mathrm{v}$ chudších zemích, aby prosadily nepopulární reformy a potlačily vzpoury. “30

25 () JAN PAVEL II., From the Justice of Each Comes Peace for All, Message of His Holiness Pope John Paul II for the Celebration of the World Day of Peace, 1. 1. 1998, \# 7 (on-line), dostupné na: http://www.vatican.va/holy_father/john_paul_ii/messages/peace/documents/hf_jp-ii_mes_08121997_xxxi-world-day-for-peace_en.html, citováno dne 20.11.2015.

26 CV 53

27 CV 33

28 Melwyn PINTO, Have We Failed Democracy in India?, Integral Liberation 15, 2/2011, s. 85.

29 () Arundhati ROY, When Corruption is Viewed Fuzzily, The Indian Express 30. 4. 2012 (on-line), dostupné na: http://www.Indianexpress.com/news/-when-corruption-is-viewed-fuzzily-/783688/0, citováno dne 20. 11. 2015.

30 () Arundhati ROY, Confronting Empire, Outlook India.com 30. 1. 2003 (on-line), dostupné na: http://www.outlookIndia.com/article. aspx?218738\#.T3rEnhKYxIU, citováno dne 4. 3. 2012. 
Tak lze ř́íci, že jedním z účinků globalizace je globalizace korupce a jejího prosazování. Její dopad lze vidět i v Indii. To je další důkaz, že ekonomie bez etiky, v níž zisk a úspěch za každou cenu jsou jediné normy, je katastrofální a nevede ke skutečnému rozvoji.

\section{Dopad globalizace na kultury}

Ačkoli globalizace je krásný ideál, v mnoha částech světa jí různé kultury kladou odpor. Na některých místech byl tento odpor násilný. Proč k tomu dochází? Jak jsme zmínili výše, globalizace má důsledky pro socioekonomický, politický, kulturní a náboženský život lidí. Globalizace má inherentní sklon přinášet $\mathrm{s}$ sebou homogenitu, nejen $\mathrm{v}$ celosvětovém obchodě, ale i v sociokulturním a náboženském životě. Zde se kultura dominantních či vlivných skupin a zemí stává normativní; jsou představovány jako ideální či globální. V důsledku toho se domorodé kultury, zvláště v chudších a slabších zemích, cítí ohroženy. Mnoho kultur považuje globalizaci za formu neokolonialismu, za další pokus Západu dobýt a zničit jejich kultury. A tak, ač na jednu stranu mnozí snad vítají výhody globalizace, cítí se ohroženi skrytou kulturní invazí ze strany dominantních hráčů globalizace. K vlivu na místní hodnoty a kultury může docházet prostřednictvím konzumního zboží a životního stylu. Mnozí v Indii se zřejmě obávají, že globalizace ohrožuje hodnoty indické kultury, zvláště ty týkající se rodinného a sexuálního života a etiky. Tato obava je zvýšena narůstajícím dosahem globálních médií, zábavy a turistického průmyslu. „Narůstající dosah globálních médií, zábavy a turistického průmyslu vyvíjí tlak na tradiční kultury a hodnoty, na smysl pro identitu a solidaritu místních společenství. “'il Např́íklad zeptáte-li se Inda, proč rozvodovost, promiskuita či předmanželský sex v Indii v posledních letech stoupá, obvykle by okamžitá odpověd' byla, že to je vliv západní kultury. ${ }^{32}$ Tato obava z kulturní invaze je také jeden $\mathrm{z}$ důvodů boje proti pozápadnění/poameričctění $\mathrm{v}$ islámském světě a narůstajících fundamentalistických tendencí v mnoha kulturách a zemích. Aby prodali výrobky a vytvořili v zákaznících pocit potřeby, aby šiŕili své hodnoty a životní styl, který podporuje jejich obchod, a aby získali snadný př́stup ke společnostem, musí zastánci globalizace vytvořit homogenní kulturu, přičemž ignorují a dokonce ničí místní kultury a jejich tradiční hodnotové systémy. Globalizace, má-li získat důvěru lidí, se musí vyvarovat této koloniální tendence: „Důvěra mezi lidmi spojenými společnými hodnotami a kulturou je ,lepidlo', které pojí místní instituce, aby se pouštěly do společných podniků. Tento sociální kapitál je pro rozvoj podstatný. Globalizace může sociální kapitál posilnit i oslabit. ${ }^{\text {“33 }}$

„Kulturní nivelizace a nekritické přijímání typů chování a životních stylü“ jsou škodlivé pro „hluboký význam kultury odlišných národů, tradic rozmanitých populací, jimiž jedinec definuje sám

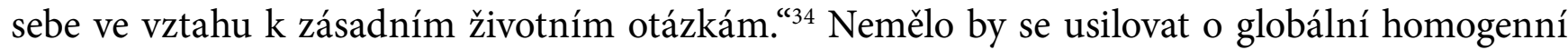
kulturu, ale o globální společenství, které dává prostor pro mnohost místních kultur. Je vhodné poslechnout si, co v tomto ohledu řekl papež Jan Pavel II.:

31 WORLD COMMISSION ON THE SOCIAL DIMENSION OF GLOBALIZATION, A Fair Globalization, č. 299 , s. 68.

32 Osobně s tímto názorem nesouhlasím. Západ také měl kulturu vysoké sexuální morálky a rodinného života díky křestanství. Nová kultura, která se chopila západní společnosti od 50. let 20. stol., není typicky západní. Není to kultura ani Západu, ani Východu, ale kultura vytvořená převážně médii a novými tržními tyrany, jejichž motivací je ideologie zisku za každou cenu. Je pravda, že tato nová kultura začala na Západě, ale dosahuje všude. Shaji George KOCHUTHARA, Sexuality: Changing Perspectives, in: Moral Theology in India Today. The DVK Workshop on Moral Theology, Bangalore: Dharmaram Publications, 2013, s. 522-523.

33 WORLD COMMISSION ON THE SOCIAL DIMENSION OF GLOBALIZATION, A Fair Globalization, č. 310 , s. 70.

34 CV 26. 
„Globalizace nesmí být nová verze kolonialismu. Musí respektovat rozmanitost kultur, které jsou interpretačními klíči života $\mathrm{v}$ univerzální harmonii národů. Zvláště nesmí zbavovat chudé toho nejcennějšího, co jim zbývá, včetně jejich náboženských věr a praktik, protože opravdová náboženská přesvědčení jsou nejjasnější manifestací lidské svobody. “35

Netvrdím, že každá kultura je dokonalá sama v sobě, ani že žádná kultura se nemá co učit od ostatních. Každá kultura má své bohatství i své nedostatky. Aby byla obohacena, měla by být každá kultura otevřena jiným kulturám, aby se od nich učila. Nemělo by se to však dít nadvládou či nivelizací kultur vnějšími činiteli. Bude-li mít úctu $\mathrm{k}$ jedinečnosti kultur, může globalizace kultury posilnit prostřednictvím zdravého dialogu založeného na solidaritě.

\section{Globalizace v solidaritě s ekologií}

Významným aspektem solidarity je solidarita s př́rodou. $V$ bezohledné honbě za ziskem je ekologická rovnováha planety a omezenost jejích zdrojů často ignorována. Bezohledné vykořistování prírodních zdrojů, ničení lesů, flóry a fauny bez ohledu na potřeby budoucích generací a technologické výdobytky, které způsobují budoucím generacím zátěž, jsou ve skutečnosti kontraproduktivní. Již nyní zakoušíme katastrofální účinky globálního oteplování způsobeného poškozením způsobeným ekologii. Nebylo by spravedlivé dávat veškeré zničení způsobené ekologii za vinu globalizaci. Ekologická krize má kořeny v modelech a taktikách rozvoje přijímaných v posledních několika desetiletích. Globalizace však zásadně posílila trendy, které ekologii ohrožují, a uvedla nové prvky. Mnohonárodní společnosti, kterým se dař́ ovlivňovat a dokonce diktovat politiky vlád, často snadno ignorují zkázu způsobenou ekologii a budoucím generacím. Rychlý růst ekonomie, který požaduje a potřebuje trh, vyžaduje rychlé a značné rozšiřování infrastruktury a těžby zdrojů. $K$ tomu je třeba přičíst povzbuzování $k$ plýtvavé spotřebě, zvláště u bohatých, bez níž současný model trhu nemůže přežít. To má za následek projekty a procesy s negativními důsledky pro ekologii. Liberalizace obchodu vedla k prudkému nárůstu $\mathrm{v}$ těžbě př́rodních zdrojů $s$ cílem získat zahraniční měnu, což má vážné důsledky pro tradiční způsoby obživy a ekologickou rovnováhu $v$ různých regionech. Normy k ochraně ekologie jsou obětovány, aby se vytvořilo „prátelské“ klima pro investice. ${ }^{36}$ Uvedu několik př́kladů zkázy způsobené ekologii v období globalizace:

Vývoz mořských výrobků z Indie stoupl z 139419 tun v letech 1990-1991 na 602835 tun v letech 2008-2009. Lze říci, že to je známka rozvoje a ekonomického zisku. Ale za jakou cenu? Za cenu vážného ekologického poškození a rozvrácení způsobů obživy tradičních rybářů a zemědělců. Studie prokázaly, že společenské a environmentální náklady pěstování krevet jsou 3,5krát vyšší než zisky. Navíc, jak se více a více oblastí konvertuje na krevetové farmy, jsou místní ryby, které jsou hlavní potravou domorodých lidí, vyhubeny. ${ }^{37}$

S liberalizací dovozu se Indie stala jedním z významných dovozců nebezpečných a toxických odpadů z průmyslových zemí. Dovoz kovových odpadů se děje v několika miliónech tun ročně. Množství dovezeného odpadu v počítačovém průmyslu také dramaticky vzrostlo. Asi 70 \% e-od-

35 JAN PAVEL II., Address to the Pontifical Academy of Social Sciences (27. 4. 2001), \# 4: AAS 93 (2001), s. 600.

36 Ashish KOTHARI, Globalization and Its Alternatives: A View from India, Policy Matters (18. 11. 2011), s. 177-179.

37 Srov. tamtéž, s. 182-183. 
padů, které se nacházejí v recyklačních zařízeních v Dillí, byly do Indie vyvezeny z průmyslových zemí. Např́klad společnost jménem Attero dostala v roce 2009 povolení dovézt 8000 tun e-odpadu. To neznamená, že za ekologické zničení Indie jsou odpovědné jen mnohonárodní společnosti. Indické společnosti (zvláště ty vlivné) je v tom následují. Další problematickou oblastí je turismus. Počet domácích turistů stoupl $\mathrm{z}$ asi 140 miliónů $\mathrm{v}$ roce 1996 na 527 miliónů $\mathrm{v}$ roce 2007 a počet zahraničních turistů z 2,29 miliónů na 5,08 miliónů. ${ }^{38}$ Pro turismus byly otevřeny ekologicky citlivé oblasti. Navíc v těchto oblastech dochází k velké výstavbě, která často porušuje všechny normy, aby se vytvořilo „přátelské“ klima pro investice do turistického průmyslu. Nedávné bleskové záplavy v Uttarkhandu, jednoho ze severoindických států v oblasti Himalájí, při nichž zahynuly tisíce lidí, převážně turisté/poutníci, jsou prý typickým příkladem katastrofálních následkủ výstavby ve jménu putování/turistiky bez ohledu na ekologii. ${ }^{39}$ Rozsáhlé oblasti, zejména venkovské a lesní, byly postoupeny národním a mnohonárodním korporacím $k$ těžbě, což vede ke zničení zemědělské půdy a lesů. Vlády (vlády států i ústřední vláda) schválily několik zákonů, které jim dovolují získávat půdu náležející zemědělcům a kmenovým př́islušníkům.

Bangalore, město, kde žiji, bylo známo jako „Zahradní město“ Indie. I dnes mnozí to jméno užívají, pochybovali bychom však, zda si to jméno ještě zasluhuje. Mnozí by řekli, že se z něj stalo odpadní město. $V$ posledních 15 letech se populace tohoto města ztrojnásobila. $V$ důsledku toho město trpí znečištěním vzduchu a vody, častými dopravními zácpami, nedostatkem otevřeného prostoru, nedostatkem vody atd. V roce 1961 mělo Bangalore 262 vodních ploch (jezer a nádrží). V období 1973-2007 došlo $\mathrm{k}$ poklesu v počtu vodních ploch o 70,69 \%, přičemž většina nastala po roce 1992. Většina $\mathrm{z}$ těchto vodních ploch byla zabrána velkými developery. $\mathrm{V}$ důsledku toho nastal za posledních 20 let pokles v hloubce spodní vody z 10-12 metrů na 100-200 metrů. ${ }^{40}$

Je zjevné, že těmto problémům nečelí Indie sama. ${ }^{41}$ Nespoutaná konkurence a bezohledné požadavky $\mathrm{v}$ trhu vedou národní a mnohonárodní korporace motivované ziskem ve všech částech světa $\mathrm{k}$ tomu, aby vykořistovaly př́rodní zdroje a prováděly výstavbové práce za cenu zničení životního prostředí. Rozvojové a chudé národy jsou tím však dotčeny závažněji. Globalizace dala mnoha mnohonárodním korporacím snadný př́stup k rozvojovým a chudým zemím, kde nejsou omezeny standardy a restrikcemi, kterými se musejí řídit ve svých domovských zemích.

Není pochyb o tom, že potřebujeme rozvoj a „přátelskou“ atmosféru pro investice národních i mnohonárodních korporací. Abychom pokryli rostoucí požadavky a byli konkurenceschopní na globálním trhu, musíme také těžit přírodní zdroje, které máme k dispozici. Náležitá otázka by byla: „Do jaké míry máme právo vykořistovat přírodní zdroje?“ Odpověd” závisí na udržitelnosti ekologického systému, skutečných potřebách lidské společnosti, úctě k celé př́rodě a potřebách př́tomných i budoucích generací. Potřeby trhu a motiv zisku by se neměly stát jedinými kritérii pro rozhodnutí využívat přírodní zdroje a výstavbu. Existuje narůstající povědomí, že „(ú)cta k př́rodě vyžaduje, aby globalizace byla ekologicky udržitelná, měla úctu k přírodní rozmanitosti

38 Srov. tamtéž, s. 184-190.

39 Ačkoli oficiálně potvrzený počet mrtvých je asi jeden tisíc, i mnoho agentur, vládních úředníků a ministrů se vyjádřilo, že skutečný počet mrtvých by mohl být mezi 10000 a 15000 .

40 Srov. Saji Mathew KANAYANKAL, Where Do We G(row)o? A Critique on „Development“ from an Ecological and Ethical Perspective, in: Moral Theology in India Today. The DVK Workshop on Moral Theology, ed. Shaji George KOCHUTHARA, CMI, Bangalore: Dharmaram Publications, 2013, s. 370-372.

41 Např. Randy J. C. ODCHIGUE ve svém článku vypráví o katastrofálních důsledcích bezohledné těžby na Filipínách (Recasting Christian and Cultural Resources for Environment and Sustainability, Asian Horizons 6, 2/2012, s. 271-286). Podobně Finomo Julia AWAJIUSUK ukazuje znehodnocení delty Nigeru v posledních letech (Genesis 1:26-28 - A Panacea for Environmental Degradation in Niger Delta, Nigeria, Asian Horizons 6, 2/2012, s. 248-260). 
života na zemi a životaschopnosti ekosystémů planety a také zajistila rovnost mezi př́tomnými a budoucími generacemi. ${ }^{{ }^{42}}$ Avšak velké obchodní podniky, které jsou motivovány jen ziskem, spolu se zkorumpovanými politiky a úředníky ignorují či porušují normy $\mathrm{k}$ ochraně ekologie, čímž maří požadavky na udržitelný rozvoj. „Rozvoj, který je veden chamtivostí, ziskem pro několik málo a nespoutaným honem za luxusem, může vést jen ke zničení životního prostředí a nakonec lidí samých. Udržitelný rozvoj bere v úvahu ochranu životního prostř̌edí. ${ }^{43}$

Papež Benedikt XVI. ve své encyklice Caritas in veritate (dále pouze CV) podtrhuje, že rozvojový model globalizace by si měl být vědom skutečnosti, že „(ž)ivotní prostředí je Boží dar pro každého, a když ho užíváme, jsme odpovědní chudým, budoucím generacím a lidstvu jako celku“.. ${ }^{4}$

Zde je třeba zmínit dvě významné znepokojující oblasti:

1. Solidarita a spravedlnost ve využití a distribuci energetických zdrojů. CV poukazuje na to, že hromadění neobnovitelných zdrojů energie některými státy, mocenskými skupinami a společnostmi klade závažnou překážku rozvoji v chudých zemích. CV vyzývá mezinárodní společenství, aby našlo „institucionální cesty, jak zavést pořádek do využívání neobnovitelných zdrojů za účasti také chudých zemí tak, aby se budoucnost plánovala společně“ ${ }^{45}$ Je také nutné přidělit více finančních prostředků pro výzkum alternativních zdrojů energie. Mnoho zemí dosud váhá investovat do alternativních zdrojů energie. Např́klad i po tragédii jaderné elektrárny Fukušima po zemětřesení 11. 3. 2011 Indie pokračuje s plánem na výstavbu řady jaderných elektráren. Byly proti tomu násilné protesty a odpor od lidí na různých místech, protože přitom mnozí přijdou o bydliště a obživu. Typickým př́íkladem je protest proti jaderné elektrárně Koodankulam ve státě Tamil Nadu. Mnozí se obávají tvrdohlavosti, s níž vláda postupuje s takovými projekty, které způsobí velké poškození ekologii na stovky let, když přitom Indie má bohaté možnosti využití sluneční energie, větrné energie a mnoha jiných alternativních zdrojů. Mnozí se ptají, zda vláda nejedná pod tlakem mnohonárodních skupin a zemí, které takové velké elektrárny instalují.

2. Je tu „naléhavá morální potřeba obnovené solidarity, zvláště ve vztazích mezi rozvojovými zeměmi a zeměmi, které jsou vysoce industrializované “46 Tato solidarita také vyžaduje snížení spotřeby energie ze strany technologicky pokročilých společností. Thomas Pogge poukazuje na to, že „bohaté země disproporčně přispívají ke globálnímu znečištění a přitom mohou užívat výtě̌̌ků svých znečištujících aktivit, aniž by daly náhradu chudým, kteří nesou hlavní nápor rizik znečištění." Chudí jsou více ohroženi zdravotními riziky a nebezpečími změny klimatu způsobené znečištěním. Podle zprávy Globálního humanitárního fóra způsobuje změna klimatu ročně ekonomické ztráty 125 miliard USD a 300000 úmrtí, z nichž 99 \% je v méně rozvinutých zemích. ${ }^{47}$ Solidarita vyžaduje, aby rozvinuté národy, které jsou více odpovědné za ekologické poškození, nesly proporcionálním způsobem povinnost kompenzovat způsobenou škodu.

Solidarita s př́rodou je vlastně globální odpovědnost, „nebot’ souvisí nejen s energií, ale $s$ celým stvořením, které nesmí být předáno budoucím generacím zbaveno zdrojü“ ${ }^{48} \mathrm{~A}$ tak solidarita

42 WORLD COMMISSION ON THE SOCIAL DIMENSION OF GLOBALIZATION, A Fair Globalization, č. 41, s. 8.

43 Julian SALDANHA, SJ, From Garden to City, Asian Horizons 6, 2/2012, s. 266.

$44 \mathrm{CV} 48$.

45 CV 49.

46 Tamtéž; srov. JAN PAVEL II., Message for the 1990 World Day of Peace, č. 13.

47 Srov. Thomas POGGE, Transcending the Washington View of Development, s. 93.

48 CV 50. 
$s$ prrírodou kromě toho, že je nutná pro bezpečný a zdravý život dnes, s sebou nese odpovědnost k budoucím generacím.

\section{Globalizace v solidaritě: několik návrhů}

Globalizace, má-li vést ke skutečnému rozvoji, by měla být založena na solidaritě. K tomu mohou být nápomocné některé návrhy předložené $\mathrm{v}$ tomto ohledu experty a světovými vůdci: ${ }^{49}$

1. Hodnoty mají být sdíleny, aniž by někdo byl vylučován, aniž by je někteří hromadili, a tak odnímali jiným právo je vlastnit. To je jeden ze základních principů k zajištění solidarity na mezinárodní i vnitronárodní úrovni. Fosilní paliva a jiné neobnovitelné zdroje energie musí být př́istupné všem národům a mělo by být upuštěno od nespravedlivých podmínek jejich produkce a distribuce, podobně i od nahodilé nadvlády nad oblastmi bohatými na palivová ložiska.

2. Mezinárodní organizace by měly zajistit spravedlivé obchodní ceny. Na základní zboží by chudé národy měly dostávat dotace. Podobně mají být nabídnuty zvláštní dotace chudým částem národa. Indie měla např́iklad systém poskytování dotací chudým. Od zavedení neoliberálního ekonomického systému bylo mnoho dotací zrušeno, zvláště pod tlakem Mezinárodního měnového fondu, Světové obchodní organizace a jiných takových organizací. Tvrdí se, že systém dotací zpomaluje ekonomický růst. Je však paradoxní, že aby se zachránily velké národní a mnohonárodní společnosti, odepisují se miliardy rupií. Ztráta pro ekonomii při odepisování dluhu mnohamiliónových společností je často mnohem větší než dotace dané chudým. Opce pro chudé je podstatným prvkem solidarity.

3. Zvláště je třeba zmínit povinnost rozvinutých/industrializovaných zemí pomáhat nejchudším. $\mathrm{V}$ mnoha př́padech je to navíc požadavek restituční spravedlnosti, tj. kompenzace za neospravedlnitelné vykořistování, které mnoho chudých zemí muselo v minulosti podstoupit. Bez štědré pomoci se mnoho takových zemí nedokáže rozvíjet, nebot dosud nemají základní vybavení a infrastrukturu. Tato pomoc by však neměla být za podmínek, které je dále zotročují.

4. Další významný aspekt solidarity, který je třeba uvážit, souvisí se zahraničními dluhy chudých národů. Kromě toho, že jsou zaostalé, většina chudých národů je přespř́lišs zatížena obrovskými zahraničními dluhy, které jim brání v rozvoji. Navíc je tyto dluhy často nutí přijmout vykořistovatelské podmínky bohatých národů a mnohonárodních korporací, což má za následek další snížení rozvoje. Nebudou-li bohaté národy ochotny vyjádřit svou solidaritu s chudými národy tím, že zruši jejich zahraniční dluhy (nebo jich alespoň značnou část odepíšou), bude pro tyto národy prakticky nemožné nalézt cestu rozvoje. ${ }^{50}$

5. Na druhou stranu mezinárodní organizace jako OSN, WTO, MMF a další poskytují velké služby tím, že podporují mír a pomáhají chudým národům v pokroku. Není však vzácné, že tyto organizace slouží zájmům bohatých a mocných, někdy i odsouvají potřeby a práva chudých zemí na vedlejší kolej. Tyto organizace se musejí stát více zastupitelskými, aby prosazovaly spravedlnost pro všechny, zvláště pro chudé a slabší národy. Současnou strukturu Rady

49 Zde odkazujeme hlavně k některým návrhům, které předložili papež JAN PAVEL II. (From the Justice of Each Comes Peace for All), Óscar Andrés kardinál Rodríguez MARADIAGA (The Catholic Church and the Globalization of Solidarity) a Thomas POGGE (Transcending the Washington View of Development). Takové nebo podobné návrhy ovšem byly vzneseny mnoha odborníky a světovými vůdci.

50 Srov. ( ) Rajesh MAKWANA, Cancelling Third World Debt, February 2006 (on-line), dostupné na: http://www.stwr.org/aid-debt-development/cancelling-third-world-debt.html, citováno dne 20. 11. 2015. 
bezpečnosti OSN nelze považovat za demokratickou, a proto je třeba ji znovu zvážit, má-li být její role a funkce výkonnější. Podobně je třeba reformulovat strukturu, členství a roli mezinárodních panelů, jako je WTO a MMF, mají-li zajistit solidaritu s chudými a slabšími národy a populacemi.

6. Je třeba znovu uvážit patentové směrnice, jimž se řídí produkce základního zboží a jeho ceny. ${ }^{51}$ To je zvlášt naléhavě pocitováno $\mathrm{v}$ př́ípadě základních léků, které mohou zachraňovat život. Při úctě k právu vynálezce a výrobce na spravedlivý zisk by se patentové směrnice měly stát citlivými k potřebám lidí, zvláště chudých. Historické rozhodnutí Nejvyššího soudu Indie, který odmítl požadavky firmy Novartis a dovolil domácím společnostem nadále vyrábět napodobeniny léku Gleevec (Glivec), dává chudým nové naděje. Zatímco Gleevec může stát 70000 USD ročně, indické značkou nechráněné verze stojí méně než 2500 USD ročně. ${ }^{52}$ Je zjevné, že mnohonárodní korporace mohou takovým krokům vzdorovat. Jsou to však nutné kroky, aby chudí a méně privilegovaní nebyli vyloučeni z výhod rozvoje.

7. Bankovnictví a úvěrový systém se musejí stát př́stupnějšími pro chudé při dostupných úrokových mírách. Jinak bude jejich finanční situace dále ovlivněna a budou marginalizováni od výhod ekonomického pokroku.

8. Vlády a nevládní organizace by měly spolupracovat, aby zajistily udržitelný rozvoj, při respektování ekologických podmínek dotčených regionů. Mělo by se více investovat do vyvíjení alternativních zdrojů energie.

9. Globalizace by měla respektovat kultury a náboženství lidí, aniž by jim vnucovala svou „homogenní" kulturu.

\section{Závěrečné poznámky}

Pastorální konstituce GS, ačkoli byla napsána několik let před nástupem globalizace, předložila vizi globalizovaného světa, $\mathrm{v}$ němž jsou různé populace a národy propojeny na základě principů spravedlnosti, solidarity a sdílení. Pozdější církevní dokumenty v této vizi globalizace pokračovaly. V posledních desetiletích se papežské dokumenty, jiné oficiální církevní dokumenty a teologové věnovali přímo skutečnosti globalizace.

Jako ideál propojenosti populací, národů a kultur nabízí globalizace velké možnosti. Aby byly uskutečněny, musí být globalizace zakotvena $\mathrm{v}$ principu solidarity, zvláště $\mathrm{s}$ chudými, $\mathrm{s}$ kulturami a s ekologií. Globalizace by neměla být především o penězích, trhu či konkurenci, ale o lidech a jejich propojenosti ve světě, který se musí stát jedinou lidskou rodinou. Ekonomická prosperita povede $\mathrm{k}$ trvalému míru a rozvoji, jen pokud zajistí spravedlnost pro všechny.

51 Abychom porozuměli rozsahu, $\mathrm{v}$ jakém jsou patentové směrnice zneužívány z obchodních pohnutek, stačí uvážit spor o patent na kurkumu, tradiční koření a lék, který se v Indii užíval po tisíce let (srov. @) http://wwwl.american.edu/ted/turmeric.htm). Jiným př́íkladem by byl spor o patent na zederach indický, léčivý strom (srov. @ http://wwwl.american.edu/ted/neemtree.htm). Byly také pokusy získat patent na rýži basmati a podobné tradiční plodiny.

52 Srov. ( ) Gardiner HARRIS - Katie THOMAS, Low-Cost Drugs in Poor Nations Get a Lift in Indian Court, New York Times 1. 4. 2013 (on-line), dostupné na: http://www.nytimes.com/2013/04/02/business/global/top-court-in-India-rejects-novartis-drug-patent.html?pagewanted=all\&_r=0, citováno dne 20. 11. 2015; @ Sakthivel SELVARAJ, Patent Justice, The Hindu 7. 4. 2013 (on-line), dostupné na: http://www.thehindu.com/news/national/patent-justice/article4588895.ece, citováno dne 20. 11. 2015. Článek Thomase Poggea zmiňovaný výše bude velmi užitečný vzhledem k patentovým směrnicím souvisejícím s léky. 


\title{
Gaudium et spes, globalizace a rozvojový svět
}

\begin{abstract}
Abstrakt
Ve svém současném významu pochází pojem „globalizace“ ze 70. let 20. století. Gaudium et spes však předkládá vizi potřeby propojeného světa, kde jsou všichni navzájem spřízněni v bratrství a solidaritě. Tento článek, inspirovaný konstitucí Gaudium et spes a pozdějšími církevními dokumenty, analyzuje globalizaci, zvláště z pohledu rozvojového světa. Jako ideál propojenosti populací, národů a kultur nabízí globalizace velké možnosti. Aby byly uskutečněny, musí být globalizace zakotvena v principu solidarity, zvláště s chudými, s kulturami a s ekologií. Globalizace by neměla být především o penězích, trhu či konkurenci, ale o lidech a jejich propojenosti ve světě, který se musí stát jedinou lidskou rodinou. Ve středu globalizace musí stát lidská osoba. Ekonomická prosperita povede k trvalému míru a rozvoji, jen pokud zajistí spravedlnost pro všechny.
\end{abstract}

Klíčová slova: globalizace, rozvojový svět, Indie, katolické sociální učení, solidarita, Gaudium et spes

\section{Kontakt na autora}

\section{Assoc. Prof. Shaji George Kochuthara}

Pontifical Athenaeum of Theology, Philosophy and Canon Law (Dharmaram Vidya Kshetram) 560029 Bangalore, India kochuthshaji@gmail.com 